\title{
A Duna „életrajza” történeti és nemzetközi jogi megközelítésből
}

\section{HUSZÁR ZOLTÁN}

\author{
„A Duna-táj bús villámhárító, \\ Fél-emberek, fél-nemzetecskék \\ Számára készült szégyen-kaloda. \\ Ahol a szárnyakat lenyesték \\ S ahol halottasak az esték. \\ »Sose lesz másként, így rendeltetett, « \\ Mormolta a vén Duna habja. \\ $S$ boldogtalan kis országok között \\ Kinyújtózott a vén mihaszna. \\ S elrohant tőlem kacagva." \\ Ady Endre: A Duna vallomása (1907) - részlet $^{1}$ \\ „A Dunának, mely mult, jelen s jövendő, \\ egymást ölelik lágy hullámai. \\ A harcot, amelyet őseink vívtak, \\ békévé oldja az emlékezés \\ s rendezni végre közös dolgainkat, \\ ez a mi munkánk; és nem is kevés." \\ József Attila: A Dunánál (1936) - részlet ${ }^{2}$
}

A Duna, amely Európa második leghosszabb folyója, eltérö földrajzi, gazdasági, politikai régiókat, különböző etnikai, vallási, történelmi múlttal rendelkezö területeket kapcsol össze, ma 10 országot érintve, 14 ország vizeit gyüjti 817 ezer km² nagyságú vízgyüjtö területe, amely a kontinens országai számára a tengerekhez történő kijutást teszi lehetövé. A folyó jelentösége abban áll, hogy fontos nemzetközi útvonal, amely Európában északnyugatról délkelet felé a Nyugat és Kelet közötti összeköttetés természetes vonalát képezi legalább kétezer év óta ennek minden előnyével és gyakran hátrányával együtt. Természetföldrajzi szerepe a történelem során mindig óriási volt, azonban nem kevésbé fontos müvelödéstörténeti szempontból sem.

A jelen tanulmányban a szerző a Duna kétezer éves „életrajzának” legfontosabb eseményeit foglalja össze történeti és nemzetközi jogi szempontból vizsgálva a témát.

Kulcsszavak: Duna, nemzetközi folyó, hajózás, Habsburg Birodalom, Nemzetközi Duna Bizottság

1 Szalatnai $1944,147$.

2 Szalatnai 1944, 160. 


\title{
The "Biography" of the River Danube from a Historic and International Legal Approach
}

\begin{abstract}
The second longest river of Europe, the Danube touches 10 countries and collects the waters of 14 countries in its $817,000 \mathrm{~km}^{2}$ large catchment basin. It is an important international waterway, provides entrance to the sea for several countries of the continent, and it is an important international waterway, a natural link between the West and the East for more than two thousand years. It connects different geographical, economic, political regions and territories with different ethnics, cultures, religions and historical past. Its historical and geographical role has always been significant, and we also have to consider it as an important component in the development of cultural history.

The aim of this study is to give a summary of the Danube's "biography" from the viewpoint of international law.
\end{abstract}

Keywords: Danube, international rivers, navigation, the Habsburg Empire, International Danube Commission

A Duna, amely Európa második leghosszabb folyója, $2850 \mathrm{~km}(2860 \mathrm{~km})^{3}-$ az első a Volga - eltérő földrajzi, gazdasági, politikai régiókat, különböző etnikai, vallási, történelmi múlttal rendelkező területeket kapcsol össze, ma 10 országot érintve, 14 ország vizeit gyűjti 817 ezer $\mathrm{km}^{2}$ nagyságú vízgyüjtő területen, ${ }^{4}$ amely a kontinens országai számára a tengerekhez történő kijutást teszi lehetővé. A folyó jelentősége abban áll, hogy fontos nemzetközi útvonal, amely Európában északnyugatról délkelet felé a Nyugat és Kelet közötti összeköttetés természetes vonalát képezi legalább kétezer éve, ${ }^{5}$ ennek minden előnyével és gyakran hátrányával együtt. Természetföldrajzi szerepe a történelem során mindig óriási volt, azonban nem kevésbé fontos művelődéstörténeti szempontból sem.

A folyók, illetve folyóvölgyek mindig meghatározóak voltak az emberiség történetében. Elég, ha az ókor nagy folyók mentén kialakult kultúráira gondolunk. A folyóvizek jelentőségét mutatja, hogy folyóhasznosításra országok, államok között már a Kr. e. 3. évezredben kötött nemzetközi szerződést két mezopotámiai város: „Umma és Lagas nemzetközi szerződéssel rendezte az öntözővíz elosztásával kapcsolatos konfliktusát." ${ }^{2}$ Egyben ez volt a világtörténelem első nemzetközi szerződése is.

A Dunát már az ókori görög források is említik. A folyó alsó szakaszát Ister (Istros), felső részét Danuvius néven emlegették. A görög mítoszokban is szerepel a folyó. Ezek szerint Herkules az Ister forrásaitól hozta az olajfaágait, amelyekkel kitüntették

3 Meyers Taschenlexikon Geschichte in 6 Bänden 1982, 64.

4 DövÉNYI-HajDú 2002, 28.

5 Weithmann német történész a Duna 3000 éves történetéről értekezik. Lásd: WEITHMANN 2000.

6 BRUHÁCS 1986, 8. 
az olimpiai győzteseket. ${ }^{7}$ A Kr. e. 8. században Hesiodosnál már olvasható az Istros folyónév. ${ }^{8}$

A Duna-medence, vagy a Duna-völgy történeti problémái dokumentálhatóan legalább a római korig nyúlnak vissza. ${ }^{9}$ A folyó már a rómaiak előtti időkben, ha csak bizonyos szakaszokon is, de hajózható volt, de szerepét az Augustus uralkodása alatt bekövetkezett hódítások növelték meg, összeköttetést biztosítva a Fekete-tenger, illetve a Balkán-vidék (Konstantinapolis), valamint Európa centruma között. ${ }^{10}$ A Duna azonban legalább annyira elválasztott, mint összekötött. A római korban a birodalom határaként szolgált Germaniától Pannonián át Daciáig, hogy a római civilizációt védje a folyó bal partján élő barbárokkal szemben. A római birodalom időszakában valósult meg, mindmáig első alkalommal, hogy a Duna egy állam területén folyt keresztül. ${ }^{11}$

A középkorban a vizek fejedelmi, főuri tulajdonná váltak, amelyekkel regáléként a tulajdonos szabadon rendelkezhetett jövedelemforrásainak gyarapítására. Ekkor alakultak ki a különböző hajó-, illetve árumegállító jogok, amelyek a hajózást és a kereskedelmet nagymértékben akadályozták. ${ }^{12}$

A középkori Magyarországon a közlekedésben a folyóknak különösen jelentős szerep jutott. A szárazföldi közlekedésben továbbra is fontosak voltak a jól megépített római utak. A középkorban nem volt szokás az útépítés, ezért a legkiszámíthatóbb nemzetközi út a Duna volt, amely európai országútnak számított. A 11-13. században elsősorban zarándokok, keresztesek és kereskedők használták a Dunát. ${ }^{13}$ A kontinens nyugati részeiből a Szentföldre induló zarándokok és keresztesek közül sokan, több hullámban a dunai útvonalat választották. A keresztes hadjáratok befejeződése után maradtak viszont a rövidebb zarándoklatok és kereskedőutak. A nyugat-európai kapcsolatokkal rendelkező dunai kereskedelem fellendülése a 13. századra tehető, amikor megindult a magyarországi városfejlődés. A Duna menti kereskedelemnek köszönhette városi kiváltságait többek között Buda (1246), Győr (1271), Pozsony (1291), de a folyótól távolabb eső Sopron (1277) is. A 14-15. században e városokban megjelenő, majd letelepedő német ajkú polgárok közül többről tudjuk, hogy rokoni kapcsolatban álltak a Duna mentén fekvő dél-német kereskedővárosok - például Regensburg - családjaival. ${ }^{14}$

A Duna, illetve a folyó melletti hadiút a 16-17. században a török európai terjeszkedésének, és a vele szemben álló Habsburg (vagy „keresztény”) hadaknak is nélkülözhetetlen közlekedési tengelye lett, amely néha segítette, de néha akadályozta is a szabad közlekedést. A Duna gyakori árvizeivel veszélyeztette a folyó környékének

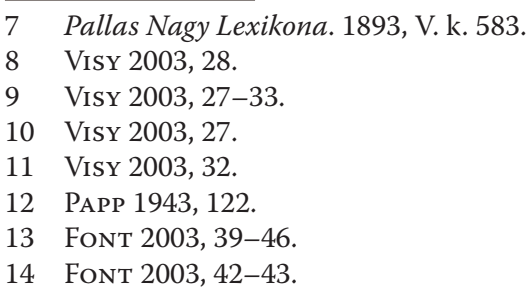


lakosságát, illetve térségét. Nem véletlen, hogy a vizekről szóló első magyar törvény is a Dunához kapcsolódik, amely I. Miksa 1569. évi XXI. törvénye: „Pozsony és Komárom vármegyék munkája felének, a szigetbe áttétele a Duna viztorkolása [sic!] gátjaihoz és töltéséhez" ${ }^{15}$ A néhány soros jogszabály világosan ír a dunai áradás következményeiről és egyben annak megelőzéséről.

Az egymással vetélkedő Habsburgok és a török porta a gazdasági szükségszerüséget felismerve, 1616-ban Bécsben szerződést kötöttek, amelyben a kereskedelem szabadságát kölcsönösen garantálták egymás területein. Az 1671-ben megalakult Levantinische Handels-Compagnie a német területek ipari termékeit és a magyar mezőgazdasági terményeket igyekezett a Dunán keletre szállítani. ${ }^{16}$

A 18. században, a Rákóczi-szabadságharc lezárulása után a Habsburg uralkodók a birodalmi gazdasági igényeknek megfelelően Magyarország mezőgazdasági terményeit rentábilis módon igyekeztek az örökös tartományok piacaira eljuttatni. Ezen elképzelés szerves részét képezte, hogy a délvidéki kiváló minőségü búza vízi úton történő szállítása érdekében folyószabályozásokat, csatornaépítéseket is folytattak. E vonatkozásban a Dunának kiemelkedő szerepe volt, de a Temest, a Bégát, a Kulpát és a Szávát is előnyben részesítették. A Béga és a Száva hajózhatóvá tétele érdekében az 1730-as években építkezések folytak, amelyek a kiújuló török háborúk miatt csak később folytatódtak. 1758 és 1763 között azonban a két folyó között csatorna épült. A dél-magyarországi vízi utak helyzete később is napirenden maradt. ${ }^{17} \mathrm{~A}$ dunai hajózás gyakoribbá a III. Károly és III. Ahmed török szultán megbízottai által 1718-ban megkötött pozsereváci béke után vált, amelyben kölcsönösen biztosították a két fél alattvalóinak szabad dunai hajózását és kereskedelmi tevékenységét. ${ }^{18} \mathrm{Az} 1738$-as belgrádi szerződésben hiába erősítették meg a pozsereváci béke Dunára vonatkozó döntéseit, a dunai hajózást nehézkessé tevő, költségeit növelő műszaki akadályok sokaságán kívül a folyómenti városok középkorból örökölt vámszedési jogai továbbra is fennmaradtak, ${ }^{19}$ annak ellenére, hogy az 1723. évi XV. tc. kimondta a folyókon való vámszedés jogtalanságát. ${ }^{20}$ Mária Terézia 1751. évi XVII., a hajóknak és tutajoknak, melyek bármely folyón föl vagy lefelé mennek, szabad átkeléséröl címü törvénycikke tovább igyekezett könnyíteni; a „hajóktól minden törvénytelen, akár a katonaság, akár a földesurak részére szedett rovatal eltörültessék". ${ }^{21}$ A 18-19. század fordulóján a Habsburg abszolutista monarchia merkantilista gazdaságpolitikájának részeként a folyami közlekedés élénkítésére és hatékonyabbá tétele érdekében csatornaépítésekkel és kezdeti folyószabályozásokkal is találkozunk. Mária Terézia hajózásról és a vízépítészeti szolgálatról hozott 1780-as rendeletének 14 pontja magas szakmai szintủ műszaki-gazdasági

15 1569. évi XXI. törvénycikk.

16 Gonda 1899, 3.

17 DóKa 2006, 2.

18 BENDA 1982, 557.

19 Gonda 1899, 4-5.

20 1723. évi XV. törvénycikk.

21 1751. évi XVII. törvénycikk. 
szakigazgatási eljárásokat írt elő. ${ }^{22}$ II. József merkantilista gazdaságpolitikájába a dunai hajózást, illetve kereskedelmet is igyekezett bevonni. 1784-ben „Sined” (sinaiai egyezmény) név alatt kereskedelmi szerződést kötött a török kormánnyal, amelyben megerősítették és kiegészítették a pozsereváci és belgrádi megállapodásokat. ${ }^{23}$ Ezek eredményeként a Habsburg uralkodó alattvalói szabad hajózást nyertek a török fennhatóság alatt lévő Duna-szakaszon és a Fekete-tengeren. Az uralkodó ösztönzése ellenére azonban a szabad hajózás lehetőségével csak kevesen éltek. ${ }^{24}$

A magyar Dél-Alföld terményeinek a Dunán Nyugat felé, Bécs irányába, illetve a Száván, Kulpán át Trieszt és Fiume felé történő szállításában fontos szerepet játszott az 1802-ben átadott, a kor legjelentősebb mesterséges vízi útja, a Tiszát a Dunával összekötő Ferenc-csatorna, ${ }^{25}$ amely átszelte a leggazdagabb gabonatermő vidékeket, és 400 km-rel rövidítette meg az utat a nyugati piacok felé. Hasonló szerepe volt a Béga-csatornának is a Bánát mezőgazdasága számára. ${ }^{26}$ (A Béga-csatorna - kisebb jelentőségű beruházásként - 1718 után, a Béga folyó környékének rendezése során készült el. ${ }^{27}$ )

A nemzetközi vízügyi kapcsolatok jogi szabályozása a 18. század utolsó harmadában kezdődött, amelynek eredményeként a 19. század végén e területen jelentős fejlődés következett be. ${ }^{28}$

A „nemzetközi folyó” fogalmával is ekkor találkozunk először, bár a terminológia a történelem során fokozatosan alakult ki. Volt időszak, amikor a kifejezést csak a hajózható folyókra alkalmazták. Mai, tágabb értelemben a nemzetközi jog szerint „nemzetközi folyók mindazok a természetes vízfolyások, amelyek [...] két vagy több államon folynak keresztül, vagy államok között határvonalat alkotnak". ${ }^{29}$

A nemzetközi folyókon a szabad hajózás elvét először az 1648. évi wesztfáliai békeszerződés mondta ki. ${ }^{30} \mathrm{Ez}$ az elv azonban még jó ideig csak papíron létezett. A preindusztriális korban a (határ)folyókra vonatkozó szerződéseknek nem tulajdonítottak nagyobb jelentőséget, azok egyszerü diplomáciai egyezséggel jöttek létre. Az ipari forradalom kiteljesedésének időszakában lett különösen fontos a nemzetközi folyami közlekedés és vízhasznosítás.

A 18. században a nemzetgazdaság fiatal tudományágának jeles képviselője, Adam Smith A nemzetek gazdagsága (The Wealth of Nations) című fő müvében, 1776-ban kifejtette azt a felfogását, hogy a több államot összekötő folyóknak milyen nagy szerepük van a kapcsolatok építésében a folyók felső folyásától egészen a tengerig. Az angol szerző példaként határozottan a Dunát említette, amelynek hajózása Bajorország,

22 Petrović 1982, 56-66.

23 BENDA 1982, 593.

24 GONDA 1899, 6-10.

25 Gonda 1899, 85-91., Petrović 1982, 56-66.

26 FónAgy 2003, 37.

27 Pallas Nagy Lexikona 1893, II. k. 820-821.; GondA 1899, 91-93.

28 BRuHÁCS 1986, 8-9.

29 Haraszti-HerCZEgh-Nagy 1983, 137.

30 Haraszti-HerCZEgH-Nagy 1983, 137. 
Ausztria és Magyarország számára nagy haszonnal járna, ha az egész Duna-szakasz a Fekete-tengerig egységes igazgatás alá kerülne. ${ }^{31}$

A francia forradalom konventje 1792-ben az emberiség alapjogaiként deklarált szabadság, egyenlőség, testvériség elvei mellett említette a szabad közlekedés jogát és a szabad hajózást a nemzetközi folyókon. ${ }^{32}$

A dunai hajózás szabadságának kérdését a nemzetközi diplomácia szintjén először 1798-ban a rastatti kongresszuson (1797-1799) a franciák vetették fel különösebb következmények nélkül. ${ }^{33}$ 1779-ben a tescheni békében - amelyet Mária Terézia és II. Frigyes porosz uralkodó megbízottai kötöttek - a Habsburgok lemondtak Bajorországról, de rögzítették a Habsburg Birodalom és Bajorország között bilaterális szerződés formájában a Duna, az Inn és a Salzach folyó közös használatának körülményeit. A szerződést 1816-ban megújították. ${ }^{34}$

Az 1814. évi párizsi szerződés nyomán - amely a Rajnára érvényesítette a szabad hajózás elvét - az 1815-ös bécsi kongresszus is foglalkozott a szabad folyamhajózás kérdéseivel. Eszerint a több államot határoló vagy átszelő folyókon mindenki számára szabad a hajózás, a hajózható ponttól a torkolatig és vissza. A kereskedelem sem tiltható meg, ha a hajózók betartják az aktuális folyamrendészeti szabályokat. A kongresszus záróokmánya, a szabad folyamhajózást kimondva, meghatározta a parti államok jogait és kötelességeit, amelyeket több folyóra alkalmaztak is, de a dokumentum a Dunát nem említette. ${ }^{35}$

A bécsi kongresszus elvi határozatai a 19. század első évtizedeiben a német területek folyói esetében az érintett parti államok egymás közötti szerződéseiben öltöttek testet. Így például a Rajna, az Odera, az Elba folyamhajózására a gyorsan változó gazdasági körülmények kényszerítették ki a konkrét szerződések megkötését. A nemzetközi folyamhajózás ügyében 1821-ben az Elba folyóról példaértékű szabadhajózási egyezmény született. Az „Elbeschiffahrtsacte” szerint a folyón Melniktől a tengerig szabad a hajózás, minden rendkívüli adószedés megszüntetendő és kizárólag a hajók és áruk után szedhető mérsékelt vám. A vámszedés jogával rendelkező helyek számát 35-ről 13-ra szállították le. A következő évtizedekben tovább könnyítették az elbai hajózás adminisztratív és technikai körülményeit, ${ }^{36}$ amit teljes mértékben a német egység létrejötte oldott meg. Az „Elbeschiffahrtsacte”, illetve annak később többször korszerűsített változata a Duna nemzetközi vízi úttá alakításában fontos, precedensértékủ dokumentum lett. ${ }^{37}$

A 19. század első felében a Duna-torkolat hajózásában Oroszországnak jutott meghatározó szerep, amely a nemzetközi dunai hajózás számára alapvetően hátrányt jelentett. Az orosz-török háborút lezáró 1812-es bukaresti béke Oroszország számára határ-

31 Strasser 1994, 133.

32 Strasser 1994, 134.

33 Pallas Nagy Lexikona 1893, V. k. 595., Révai Nagy Lexikona, VI. k., 1982, 64.

34 Pallas Nagy Lexikona 1893, V. k. 595., BENDA 1982, II. k. 590.

35 Palotás 1984, 9-10.

36 Pallas Nagy Lexikona 1893, V. k. 833.

37 Palotás 1984, 25. 
ként a Kilia-ágat jelölte meg. 1826-ban Oroszország megszerezte a Sulina-ág, 1829-ben, a drinápolyi békeszerződésben a legdélibb, a Szent-György-ág feletti ellenőrzést is, aminek eredményeként az egész Duna-delta orosz fennhatóság alá került. A szerződés elvileg kimondta a kereskedelem és a dunai hajózás liberalizálását. A gyakorlatban azonban az orosz felügyelet alatt a különböző vámok, vesztegzárak alkalmazása, valamint a Duna-delta folyamszabályozásának elmaradása következtében jelentkező eliszaposodás egyértelműen hátrányosan befolyásolta a hajózást. A Habsburg Birodalom és Oroszország között 1840-ben létrejött szerződésnek, amely a fenti problémák kiküszöbölését szolgálta, nem sikerült a gyakorlatban érvényt szerezni. A Szentpéterváron aláírt megállapodás volt az első olyan jogi okmány, amelyben mindkét szerződő fél kinyilvánította azon szándékát, hogy a területéhez tartozó Duna-szakaszon alkalmazzák az 1815-ös bécsi kongresszuson született szabad hajózásra vonatkozó határozatokat, amelyek közül kiemelkedik az az elv és gyakorlat, hogy a folyón a kereskedelem senkinek sem tiltható meg, továbbá a megállapított illetékeken kívül semmilyen egyéb akadályozó tényező, például vám nem alkalmazható. Oroszország vállalta, hogy a fennhatósága alatt lévő Duna-delta Szulina-ágát hajózható állapotba hozza, illetve abban tartja. Ezen utóbbi ígéret azonban a következő években sem valósult meg. ${ }^{38}$

1851-ben a Habsburg Birodalom Bajorországgal kötött folyamhasználati szerződést, amely a két fél vízi útjain történő hajózást egymás számára jelentősen megkönynyítette. $^{39}$

A fent vázolt Duna-hajózási egyezmények és azok betartásának nehézségei ellenére a Duna-torkolatban élénk hajóforgalom volt már az 1840-1850-es években.

Az Európai Duna Bizottság (EDB) által készített összeállítás azt mutatja, a hajószámra és a szállított áru tonnában megadott mennyiségére lebontva, hogy a jelzett időszakban (1847-1856) mely országok küldtek hajókat, illetve árut a Duna torkolatába. A „hajók száma” rovat nem tesz különbséget a hajótípusok között, így nem tudjuk, hogy mennyi volt a gőzhajó és az egyéb - evezős, vitorlás - hajó. Henry Hajnal statisztikája kivételt tesz az osztrák és a francia gőzösök esetében. ${ }^{40}$ Biztosan állíthatjuk, hogy az osztrák gőzhajók a DGT és/vagy az Osztrák Lloyd tulajdonában voltak. A táblázatból viszont világosan látszik, hogy a Duna-torkolat közelében lévő nagy hajózási hagyományokkal rendelkező országok - Görögország, Törökország - hajói szállították a legtöbb árut. Ugyanakkor, ha összeadjuk az „Ausztria-Magyarország” és az „Osztrák gőzhajók” által szállított áruk súlyát, akkor a görög áruszállítás nagysága utáni 2. helyet érik el a Habsburg Birodalomból érkezett hajók.

Az EDB által készített 1. táblázat azt mutatja - a hajószámra és a szállított áru tonnában megadott mennyiségére lebontva - hogy a jelzett időszakban (1847-1856) mely országok küldtek hajókat, illetve árut a Duna torkolatába.

A 2. táblázat pedig azt, hogy mely országok tulajdonában voltak az Al-Dunán kereskedelmi tevékenységet folytató hajók.

38 Fekete 1984, 437-438., Palotás 1984, 11-12.

39 Pallas Nagy Lexikona. 1893, V. k. 597.

40 Hajnal 1920, 164-165. 


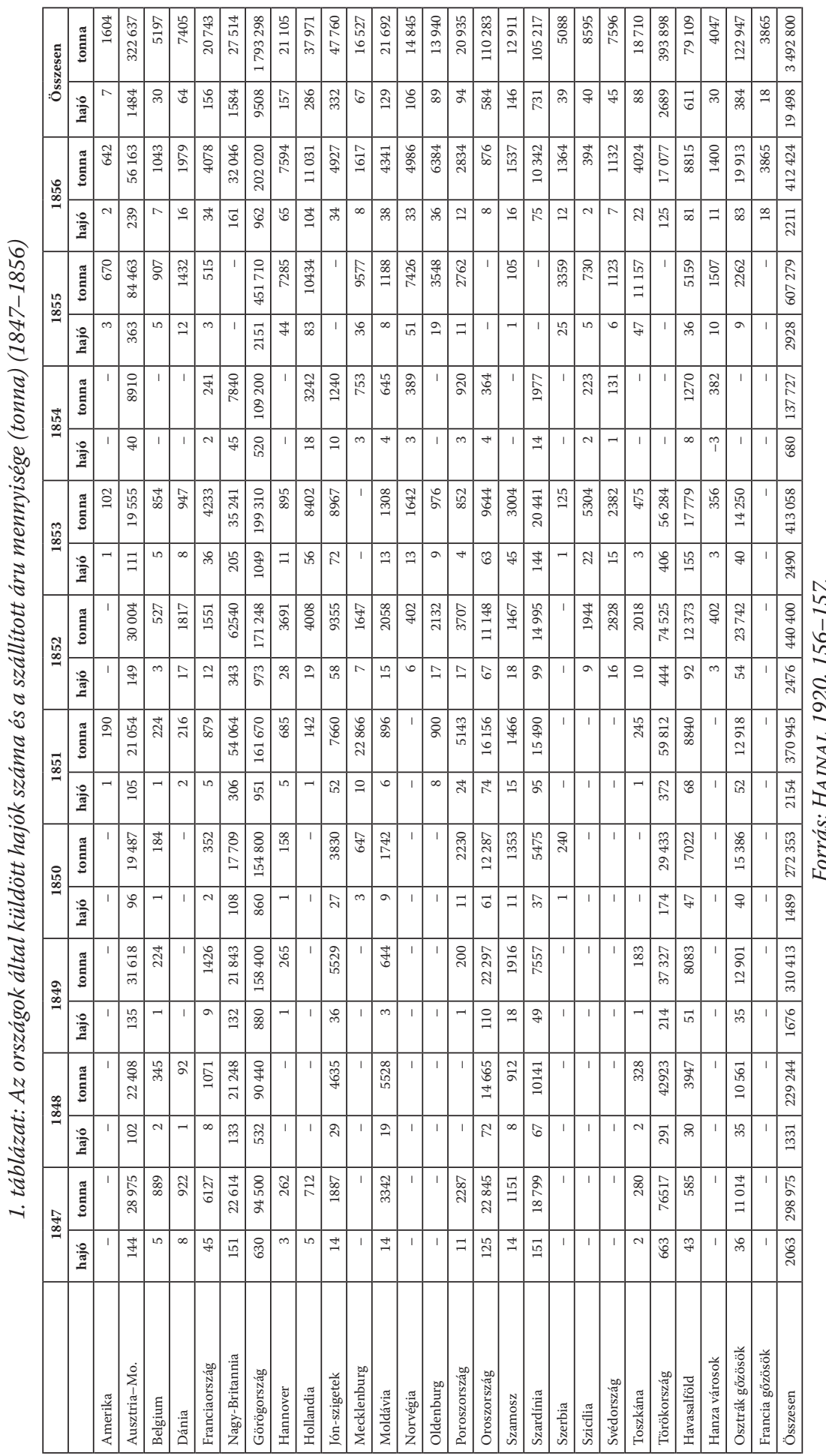




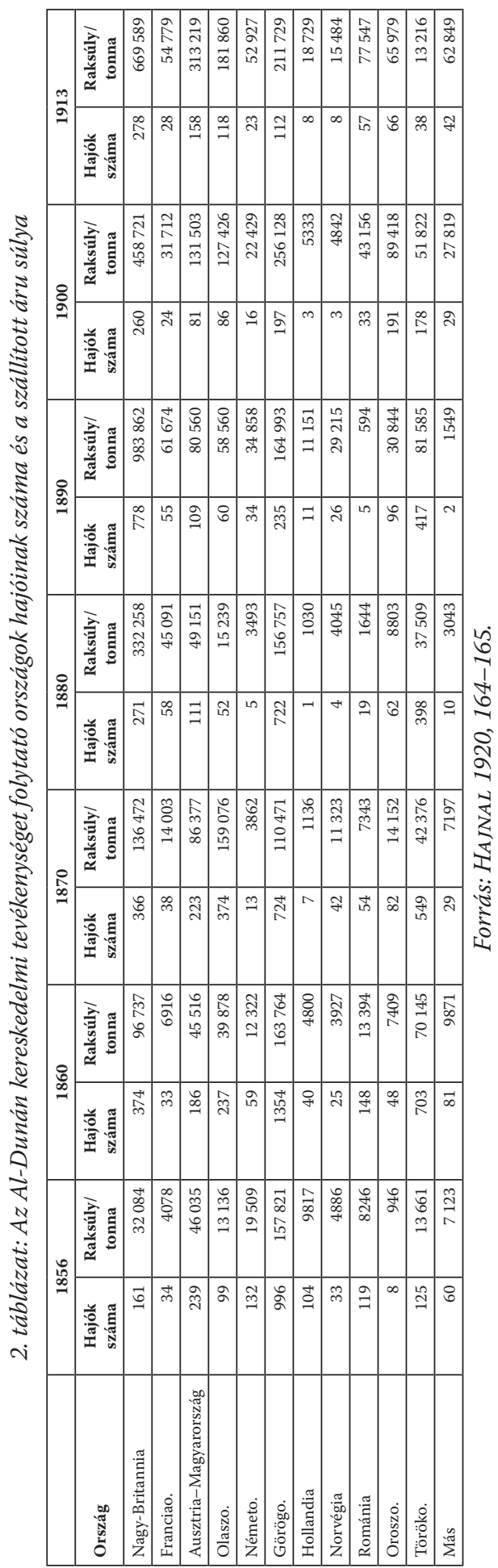


A Duna-probléma önálló nemzetközi szerepe a krími háború idején (1853-1856) ${ }^{41}$ kezdődött, és utána is megmaradt. Az Oroszországgal szemben szövetkezett hatalmak a béke előfeltételéül szabták a Dunán a szabad hajózás biztosítását. A háborút lezáró 1856 . március 30 -án aláírt párizsi békeszerződés ${ }^{42}$ a besszarábiai határrendezés keretében Oroszországot megfosztotta a Duna-melléki területektől, a Duna-deltától, valamint a nem Duna-parti államoknak is garantálta a szabad hajózást a folyón. A békeszerződés 15. cikkelye kimondta, hogy az 1815-ös bécsi kongresszus záródokumentumában rögzített elveket kell alkalmazni a Dunára vonatkozóan, ami alapvetően a szabad hajózás elvének gyakorlatba való átültetését jelentette. Ennek betartását Európa (az aláíró felek) kollektíven garantálta. Továbbá azt is rögzítették, hogy a szabad hajózást semmilyen módon nem lehet akadályozni, a hajókon szállított áruk után nem szedhető vám vagy adó. A folyó igazgatására két nemzetközi szervezetet hoztak létre. Az Európai Duna Bizottságot (a továbbiakban: EDB), amelynek tagjai a nagyhatalmak, tehát a Habsburg Birodalom - nem parti államként - Franciaország, Anglia, Poroszország, Oroszország, a háborúban győztesen felemelkedő Szárd-Piemonti Királyság (később az egységes Olaszország) és - parti államként - Törökország. Az EDB hatásköre Iszakcsától (Isaccea) Sulináig terjedt ki. Székhelyéül Galacot választották. Kimondatlanul is fontos volt a tagok számára, hogy a bizottságban a nagyhatalmak legalizálták délkelet-európai jelenlétüket. A bizottságot eredetileg ideiglenes jelleggel - kétéves időtartamra - hívták életre a Duna-torkolat hajózási és müszaki problémáinak az elhárítására, illetve az adott folyammeder karbantartására. A szükséges munkák elvégzésének a finanszírozását az áthaladó hajóktól beszedett illetékekből kellett előteremteni. E vonatkozásban minden nemzet hajója egyenlő elbánásban részesült. A másik bizottság az állandónak szánt Parti Államok Bizottsága, vagy Folyami Bizottság néven vált ismertté. Tagjai a Habsburg Birodalom, Törökország, Württemberg, Bajorország, a három dunai fejedelemség - Moldva, Havasalföld és Szerbia - küldöttei, akiket a török porta egyetértésével jelöltek ki. Székhelye Bécs lett. Feladata a hajózási és folyamrendészeti szabályok kidolgozása és érvényesítése Iszakcsától felfelé az egész Dunára vonatkozóan, a hajózást gátló műszaki akadályok elhárítása, valamint a Bizottság által felügyelt Duna-szakasz teljes hosszában szükséges karbantartások elrendelése és irányítása, továbbá az ideiglenesnek szánt EDB mandátumának lejárta után az EDB jogköreinek átvétele, valamint a Duna-torkolatok és tengerrészek hajózhatóságának felügyelete volt. A Parti Államok Bizottságának munkáját a párizsi békét aláíró nem parti államok (nagyhatalmak) nem támogatták. Ezért e szervezet nem tudott hatékony tevékenységet kifejteni. ${ }^{43} \mathrm{~A}$ párizsi békeszerződés XV. passzusa, amely a dunai hajózás szabadságát - a bécsi kongresszus elveinek megfelelően - deklarálta, a bécsi udvarban negatív visszhangot váltott ki. Ennek a Dunagőzhajózási Társaság dunai hajózási monopóliuma szempontjából volt külö-

41 Kinder-Hilgemann 1995, 347.

42 Palotás 1984, 21-23.

43 Pallas Nagy Lexikona 1893, V. k. 596., Palotás 1984, 21-22. 
nösen nagy jelentősége. ${ }^{44}$ A Parti Államok Bizottsága Bécsben új nemzetközi Dunahajózási szerződést dolgozott ki, amelyet 1857. november 7-én a négy szuverén állam, Ausztria, Württemberg, Bajorország és Törökország írt alá. (A három dunai fejedelemséget nem hívták meg az aláírásra a török tiltakozás miatt.) A Duna-hajózási okmányban (Acte de navigation du Danube), amelyet az aláíró országok ratifikáltak, tulajdonképpen a párizsi békeszerződés Parti Államok Bizottságára ruházott feladatait konkretizálták. (Folyamhajózás biztosítása, folyamrendészeti teendők stb.) ${ }^{45}$

Az EDB működését a 19. század második felében többször is meghosszabbították, először az 1858-as II. párizsi kongresszus, amelyen az EDB angol és francia tagjai nem fogadták el az 1857-es Duna-hajózási okmányban leírtakat. Az 1866-os III. párizsi kongresszus határozatai nyomán a szervezet folyamatosan ellátta feladatait. ${ }^{46}$

Az 1878-as berlini kongresszus egyik legfontosabb határozata a Dunához kapcsolódott, amely az Al-Duna biztonságos hajózhatóvá tétele érdekében született. A kongresszus döntése nyomán az Osztrák-Magyar Monarchiát bízták meg a feladat elvégzésével. ${ }^{47}$ Az Al-Duna - Kazán-szoros, Zuhatagok, Vaskapu - szabályozás nagy munkáját a magyar kormány vállalta magára. A közel két évtizedes, változó intenzitású folyószabályozás után 1896. szeptember 27-én adták át a forgalomnak a Zuhatagosszakaszt és a Vaskapu-csatornát. ${ }^{48}$ Ezzel a Dunán megvalósult a folyamatos, átrakás nélküli hajózás lehetősége.

Az 1883. évi londoni konferencián az EDB mandátumának újabb, immár 21 évre történő meghosszabbítását fogadták el olyan módon, hogy a lejáratkor újabb 3 évre meghosszabbodik a mandátum mindaddig, amíg a bizottság valamely tagja a lejárat előtt egy évvel nem emel ez ellen kifogást. Az EDB gyakorlatilag az első világháborúig változatlan formában fennállt. Ezen a konferencián döntöttek a Vaskaputól Brailáig terjedő szakasz egységes hajózási és folyamrendészeti felügyeletére vonatkozó szabályzatról. ${ }^{49}$

Az első világháború befejeződése után a győztes hatalmak érdekei érvényesültek a dunai hajózásban is. 1918-ban a győztesek egy dunai hajózási parancsnokságot (Commandenet de la Navigation du Danube) állítottak fel Ernest Troubridge ${ }^{50}$ angol admirális vezetésével. A szervezet székhelye előbb Belgrád, majd Budapest lett. Később a parancsnokság - Commission Interalliée du Danube néven - politikai jellegű bizottsággá alakult át. A bizottság a szövetséges haderők forgalmi és élelmezési szükségleteinek a vízi úton történő ellátását, a folyami hajózás háború előtti

44 PALOTÁs 1982, 22., 25.

45 PALOTÁs 1984, 28-29.

46 Fekete 1984, 438., Palotás 1984, 29-30.

47 FЕКеTE 1984, 438.

48 FEKETE 1984, 438.

49 Fekete 1984, 438., Palotás 1984, 148-150.

50 Ernest Troubridge admirális az első világháború utáni években a dunai angol misszió parancsnoka és egyben az Európai Duna Bizottság elnöke volt. Kezdeményezésére és javaslatára lett a Duna hajózási szempontból nemzetközivé nyilvánítva, s ennek megfelelően jött létre 1921-ben a Comission Internationale du Danube (CID), a Nemzetközi Dunabizottság szervezete. Lásd: MARCzIs 1995, 86. 
viszonyainak a visszaállítását és a központi hatalmaktól lefoglalt hajók használatbavételét, valamint a volt magyar Vaskapu-szolgálat továbbfolytatását tüzte ki feladatul. ${ }^{51}$

A nemzetközi folyók problémáját ${ }^{52}$ lényegében azonos tartalmú szabályozással kezelték a világháborút lezáró versailles-i békeszerződésekben, így a saint-germaini, ${ }^{53}$ a trianoni, ${ }^{54}$ a sevres-i, illetve ennek helyébe lépő lausanne-i szerződésben ${ }^{55}$ is. A Duna-kérdést a Magyarországgal megkötött trianoni békeszerződésben (1920) igyekeztek a győztesek számukra a legkedvezőbben megoldani. A békeszerződés több pontja is foglalkozik a Dunával. A XII. rész 274-293. cikkelye tárgyalja a Dunára vonatkozó előírásokat. ${ }^{56}$ Alapvetően a hajózás szabadságának szellemében íródott cikkelyek között több ellentmondás fedezhető fel. Nem azonos lehetőségeket biztosítottak a Szövetséges és Társult hatalmak, illetve Magyarország állampolgárai számára „a hajózás szabadsága szellemében” ${ }^{57}$ az Ulmtól nemzetközinek nyilvánított Dunán. Így az a különös és igazságtalan helyzet állt elő, hogy Magyarország - és a többi legyőzött dunai állam - nem folytathatott a Duna-menti kisantant államok kikötői között „cabotage" ${ }^{58}$ hajózást, míg Magyarországon akár egy győztes nem parti állam a magyar kormány hozzájárulása nélkül is szabadon szállíthatott az egyik magyar kikötőből a másik magyar kikötőbe személyeket vagy árukat. ${ }^{59} \mathrm{~A}$ békeszerződés 284 . cikkelye rendelkezett a győztes hatalmak részére történő hajópark átadásáról. ${ }^{60}$

A Dunára vonatkozó különös szabályok között a nemzetközi szervezetek működését is megerősítették a békeszerződés összeállítói. „Az Európai Dunabizottságnak [EDB - H. Z.] újból az a hatásköre lesz, amely a háború előtt megillette. Egyelőre azonban csak Nagybritannia, Franciaország, Olaszország és Románia képviselői lesznek tagjai ennek a Bizottságnak." ${ }^{1}$

A következő cikkely a korábbi - gyakorlati tevékenységet nem folytató - Parti Államok Bizottságát újította fel. ${ }^{62}$

Mint a fentiekből látható, az EDB az első világháborút lezáró versailles-i békeszerződések után is fennmaradt, működését az 1921. évi párizsi konferencián született Duna-akta (vagy Párizsi Duna Konvenció) garantálta. Az így megerősített bizottságban azonban a világháború utáni nemzetközi helyzetnek megfelelően Anglia, Franciaország, Olaszország mint nagyhatalmak, és Románia mint parti állam vet-

51 PAPP 1943, 132.

52 BRUHÁCS 1986, 120.

53 Kerekes 1984, 42-49., Zöllner 1998, 371-378., SzÁvai 1999, 31-42., SzÁvai 2004, 45-106.

54 Ormos 1984, 369-386., Ormos 1998, 81-85., Szávai 1999, 31-42., SzÁvai 2004, 45-106.

55 TARJÁn (é. n.)

56 1921. évi XXXIII. törvénycikk 274-293. cikk.; ZEIDLER 2003, 270-274.

57 1921. évi XXXIII. tc. 274. cikk; Uo.

58 Cabotage joga: (fr.) Ugyanannak az államnak a területéhez tartozó folyószakaszon levő két kikötő között a személy- és áruforgalom lebonyolításának joga kizárólag a parti államot illeti meg. Haraszti-HerCZegh-Nagy 1983, 138.

59 PAPP 1943, 124.

60 1921. évi XXXIII. tc. 284. cikk; Uo.

61 1921. évi XXXIII. tc. 285. cikk; Uo.

62 1921. évi XXXIII. tc. 288. cikk; Uo. 
tek részt. ${ }^{63}$ A párizsi konferencián hozták létre azt a Nemzetközi Duna Bizottságot, amelynek Anglia, Ausztria, Bulgária, Csehszlovákia, Franciaország, Jugoszlávia, Magyarország, Románia és a két felső-dunai német tartomány, Bajorország és Württemberg lettek a tagjai. Felállították továbbá a Duna zuhatagos szakaszára a Vaskapu- és a Zuhatagok Igazgatóságát Jugoszlávia és Románia képviselőiből és a Nemzetközi Duna Bizottság részvételével. ${ }^{64}$

A trianoni békeszerződés, az 1921. évi és 1923. évi párizsi egyezmények a területi változások miatt a Duna-medence vízhasznosítására és árvízvédelmére elveket állapítottak meg, amelyeket az érintett országoknak kétoldalú szerződésekben kellett rendezni. ${ }^{65}$ A „Dunára vonatkozó végleges szabályzat megállapítása tárgyában 1921. július hó 23-án Párizsban kelt egyezmény becikkelyezése" az 1923. évi XIV. törvénycikkben történt meg. ${ }^{66}$

Jelentős előrelépésnek számított 1923-ban a CRED ${ }^{67}$ létrehozása, amelynek tagjai: Ausztria, Magyarország, Románia, Szerb-Horvát-Szlovén Királyság (Jugoszlávia) és Csehszlovákia lettek, valamint a Nemzetek Szövetsége Tanácsa által megbízott elnök. ${ }^{68}$ A CRED minden, a szervezethez tartozó állam számára fontos, egyénileg és/vagy közösen megoldandó szakmai feladatok megtárgyalásának a fóruma volt. $\mathrm{Az}$ „erdőkihasználás és újbóli fásítás” kérdésében minden bizonnyal Magyarországon az egyik első aktív környezetvédelmi, környezettudatos jogalkotási pillanat ragadható meg a dokumentum olvasásakor. A szervezet szakszerűségét nem lehet kétségbe vonni, ezt a kortársak sem tették. A CRED működése során jelentős eredményeket ért el a vízállás- és árvízjelzési szolgálat működtetésében. Tevékenysége azonban a második világháború alatt megbénult. Az 1920. évi trianoni békeszerződés helyére lépő 1947. évi párizsi békeszerződés nem tartotta fenn a szervezetet, ezért az megszűnt. ${ }^{69}$

A dunai nagyhatalmi és román érdekek megerősítésére 1938-ban Anglia, Franciaország és Románia között megkötött sinaiai (szinajai) egyezmény alapján létrehozták a Román Tengeri Duna Bizottságot. ${ }^{70} \mathrm{~A}$ részleteiben egymásnak gyakran ellentmondó bizottsági munka 1938-tól, az Anschlusst követően még nehezebbé vált, ugyanis a hitleri Németország Pozsonytól felfelé német nemzeti folyónak nyilvánította a Dunát, így annak nemzetközi jellege jórészt megszűnt. A sinaiai egyezményhez

63 Haraszti-Herczegh-Nagy 1983, 139.

64 Haraszti-Herczegh-Nagy 1983, 139., Fekete 1984, 438.

65 BRUHÁCS 1986, 123. Az 1925. évi VII. törvénycikkben került a magyar jogrendbe a nevezett szerződés. (Magyarország és a Duna-medence államainak két világháború között megkötött vízügyi bilaterális szerződései érdekes témát jelenthetnek, de a jelen tanulmány fő vonalától távol esnek. Bruhács János alaposan vizsgálta a kérdést. BRUHÁcs 1986, 122-129.)

66 1923. évi XIV. törvénycikk.

67 CRED = Comission technigue permanente du régime des eaux; magyarul = Dunai Állandó Vízügyi Műszaki Bizottság. BruHÁCs 1983, 289.

68 Az 1925. évi VII. törvénycikk címe: A Dunai Állandó Vízügyi Müszaki Bizottság hatáskörére és müködésére vonatkozó szabályzat jóváhagyása tárgyában 1923. évi május hó 27-én Párisban kötött egyezmény becikkelyezéséről.

69 BRUHÁCS 1986, 128.

70 Haraszti-Herczegh-Nagy 1983, 139.; Fekete 1984, 438. 
bukaresti egyezmény néven 1939. március 1-jén Németország és Olaszország is csatlakozott. Mindezek alapvetően megváltoztatták a dunai hajózás addigi nemzetközi rendjét. Az EDB gyakorlatilag elveszítette felügyeletét a hajózás felett. Ezt követően a hitleri Németország 1940. szeptember 12-én Bécsben Bulgária, Jugoszlávia, Magyarország, Németország, Olaszország és Szlovákia részvételével konferenciát hívott össze, ahol az 1921-ben Párizsban megalakult Nemzetközi Duna Bizottság megszüntetését határozták el, és egyidejűleg létrehoztak egy új igazgatási szervezetet, a Dunatanácsot ${ }^{71}$ vagy Folyami Tanácsot. ${ }^{72} \mathrm{~A}$ Dunatanács albizottságaként hívták életre az al-dunai Vaskapu igazgatására az „Eisene Torvervaltung”73 nevü intézményt, amely a nevezett szakasz forgalmi és azzal összefüggő ügyeinek intézéséért volt felelős. Mindezek a változások már a világháborús előkészületekként értelmezhetők.

A második világháború befejeződése után megkötött versailles-i békeszerződés területi kérdésekben Magyarország számára - a pozsonyi hídfö három, Csehszlovákiának juttatott településén kívül - a gyakorlatban a trianoni békeszerződést ismételte meg. A pozsonyi hídfó átengedése miatt a Dunához kapcsolódó vízügyi rendelkezések is bekerültek a békeokmányba. ${ }^{74} \mathrm{~A}$ békeszerződés azonban nem említette a dunai hajózás, illetve a vízhasználat kérdéseit. E problémákkal a „Külügyminiszterek Tanácsának 1946. évi december hó 12-én kelt határozatára”75 alapuló „a Dunán való hajózás rendjének szabályozása tárgyában Belgrádban 1948. évi augusztus hó 18. napján kelt nemzetközi Egyezmény"76 foglalkozott. A belgrádi nemzetközi konferencia részletesen szabályozta a dunai hajózás körülményeit. Az egyezmény határozatainak aláírói: Csehszlovákia, Magyarország, Jugoszlávia, Románia, Bulgária, Ukrajna és a Szovjetunió. A konferencián részt vettek Nagy-Britannia, Franciaország és az Amerikai Egyesült Államok képviselői is, akik viszont nem írták alá a záródokumentumot. A hét parti állam létrehozta a Duna Bizottságot, amely „a dunamenti országok képviselőiből alakul, akként, hogy mindegyik ország egy-egy képviselőt küld." ${ }^{77}$ A Bizottság székhelye Galac, majd 1953-tól Budapest lett. (Ausztria 1960-ban csatlakozott az egyezményhez, a Német Szövetségi Köztársaság megfigyelői minőségben vett részt a Duna Bizottság munkájában. ${ }^{78}$ ) Az egyezmény aláírói a Dunát Ulmtól a Fekete-tengerig tekintették hajózhatónak. Valamennyi állam számára biztosították a kereskedelmi hajózás lehetőségét. A nem parti államok hadihajói a Dunán egyáltalán nem közlekedhettek, a parti államok hadihajói pedig csak a saját folyószakaszukat használhatták. Más parti állam folyószakaszán csak az illető állam/ államok engedélyével közlekedhettek hadihajók.

71 PApp 1943, 133. A Dunatanács hivatalos neve: „Beratender Ausschuss für Donauangelegenheiten oberhalb Braila".

72 Haraszti-Herczegh-Nagy 1983, 139.; Fekete 1984, 438.

73 PAPP 1943, 133.

74 1947. évi XVIII. törvénycikk indokolása.

75 1949. évi XIII. törvény.

76 1949. évi XIII. tc.; Uo.

77 1949. évi XIII. tc. II. fejezet 1. rész; Ua.

78 Haraszti-HercZegh-Nagy 1983, 139. 
A Duna mint nemzetközi folyó életrajza a második világháború után a bipoláris világ létrejöttével párhuzamosan tovább bonyolódott, ami viszont egy következő tanulmány témája lehetne.

\section{Felhasznált irodalom}

BENDA Kálmán szerk. (1982): Magyarország történeti kronológiája II. 1526-1848. Budapest, Akadémiai Kiadó.

BRUHÁCs János (1986): Nemzetközi vízjog. A nemzetközi folyóvizek nem hajózási célú hasznositásának joga. Budapest, Akadémiai Kiadó.

DóкA Klára (2006): A Duna mappáció (1823-1845) Történeti áttekintés. In Tóтн. G. Péter szerk.: A Duna-mappáció. A Duna folyó magyarországi szakaszának térképei. (1819-1833) az osztrák határtól Péterváradig. (Digitális forráskiadvány. DVD-Rom) Pécs, Médiatér Kft.

DövÉNYI Zoltán - HajDú Zoltán szerk. (2002): A magyarországi Duna-völgy területfejlesztési kérdései I. $k$. Budapest, Magyar Tudományos Akadémia.

FEKETE György (1984): A Duna menti államok együttműködése a hajózásban. In: Közlekedéstudományi Szemle, 34. évf. 10. sz. 437-442.

FónAgy Zoltán (2003): A bomló feudalizmus gazdasága. In Gergely András szerk.: Magyarország története a 19. században. Budapest, Osiris Kiadó. 26-56.

FonT Márta (2003): Zarándokok, keresztesek és kereskedők a Duna mentén a 11-13. században. In Huszár Zoltán - VÁndor Andrea - Walterné Müller Judit szerk.: 2000 év a Duna mentén / 2000 Jahre entlang der Donau. Pécs, Baranya Megyei Múzeumok Igazgatósága, Janus Pannonius Múzeum. 39-46.

Gonda Béla (1899): A magyar hajózás. Budapest, Műszaki, Irodalmi és Nyomdai Vállalat.

Hajnal, Henry (1920): The Danube. Its Historical, Political, and Economic Importance. The Hague, Martinus Nijhoff.

Haraszti György - Herczegh Géza - Nagy Károly (1983): Nemzetközi jog. Budapest, Tankönyvkiadó.

KereKes Lajos (1984): Ausztria hatvan éve 1918-1978. Budapest, Gondolat Kiadó.

Kinder, Hermann - Hilgemann, Werner (1995): SH Atlasz. Budapest-Berlin, Springer-Verlag.

Marczis Ervin (1995): 100 éves a Magyar Állami Hajózás. Budapest, MAHART Hajózási Rt.

Meyers Taschenlexikon Geschichte in 6 Bänden. (1982) Band 2. Bibliographisches Institut Mannheim/Wien/Zürich, Meyers Lexikonverlag.

Ormos Mária (1984): Padovatól Trianonig 1918-1920. Budapest, Kossuth Könyvkiadó.

Ormos Mária (1998): Magyarország a két világháború korában 1914-1945. Debrecen, Csokonai Kiadó.

Pallas Nagy Lexikona. (1893) Budapest, Pallas Irodalmi és Nyomdai Részvénytársaság.

Palotás Emil (1984): A nemzetközi Duna-hajózás a Habsburg-Monarchia diplomáciájában 1856-1883. Értekezések a Történettudományok Köréből 104. Budapest, Akadémiai Kiadó.

PApp Remig (1943): Belvízi hajózás. A Mérnöki Továbbképző Intézet Kiadványai XVII. kötet, 39. füzet, Budapest.

Petrović, Nikola (1982): Hajózás és gazdálkodás a Közép-Duna-medencében a merkantilizmus korában. A Duna-Tisza csatorna építése és fáradozások a Közép-Duna-medence és az Adriaitenger összekötésére a XVIII. század végén. Beograd - Novi Sad, Vajdasági Tudományos és Müvészeti Akadémia Történelmi Intézet. 
Révai Nagy Lexikona VI. k.

Strasser, Hellmuth (1994): Die Internationalisierung der Donau. In LitsChel, Helga ed.: Die Donau. Facetten eines europäischen Stromes. Katalog zur oberösterreichischen Landesausstellung 1994 in Engelhartzell. Linz, Landesvertrag AG im Veritas-Verlag.

Szalatnai Rezső (1944): A Duna költői. Öt évszázad versei a Dunáról. Budapest, Hungária Kiadás.

SzÁvai Ferenc (1999): Az Osztrák-Magyar Monarchia közös vagyona. Pécs, Pro Pannonia Kiadói Alapítvány.

SzÁvai Ferenc (2004): Az Osztrák-Magyar Monarchia felbomlásának következményei. Az államutódlás vitás kérdései. Pécs, Pro Pannonia Kiadói Alapítvány.

TARJÁN M. Tamás (é. n.): 1923. július 24. Az I. világháború utolsó békeszerződése. Rubicon. Elérhető: www.rubicon.hu/magyar/oldalak/1923_julius_24_az_i_vilaghaboru_utolso_bekeszerzodese/ (2019. 02. 17.)

VIsY Zsolt (2003): A Duna szerepe és jelentősége a római kori Kárpát-medencében. In HuszÁR Zoltán - VÁNdor Andrea - WAlterné Müller Judit szerk.: 2000 év a Duna mentén / 2000 Jahre entlang der Donau. Pécs, Baranya Megyei Múzeumok Igazgatósága, Janus Pannonius Múzeum. 27-33.

Weithmann, Michael W. (2000): Die Donau. Ein europäischer Fluss und seine 3000-jährige Geschichte. Styria-Graz-Wien-Köln, Verlag Friedrich Pustet Regensburg.

Zeidler Miklós szerk. (2003): Trianon. Nemzet és Emlékezet. Budapest, Osiris Kiadó.

ZöLlNER, Erich (1998): Ausztria története. Budapest, Osiris Kiadó.

\section{Jogforrások}

1569. évi XXI. törvénycikk Pozsony és Komárom vármegyék munkája felének, a szigetbe áttétele a Duna viztorkolása gátjaihoz és töltéséhez. Elérhető: https://net.jogtar.hu/ezer-ev-torveny?docid=56900021.TV\&searchUrl=/ezer-ev-torvenyei\%3Fpagenum\%3D13 (2019. 02. 17.)

1723. évi XV. törvénycikk a száraz és nem szükséges vámoknak, még a folyóvizieknek is, eltörléséről, s a zsidók elmozditásáról. Elérhető: https://net.jogtar.hu/ezer-ev-torveny?docid=72300015. TV\&searchUrl=/ezer-ev-torvenyei\%3Fpagenum\%3D24 (2019. 02. 17.)

1751. évi XVII. törvénycikk a hajóknak és tutajoknak, melyek bármely folyón föl vagy lefelé mennek, szabad átkeléséről. Elérhető: https://net.jogtar.hu/ezer-ev-torveny?docid=75100017.TV\&searchUrl=/ezer-ev-torvenyei\%3Fpagenum\%3D25 (2019. 02. 17.)

1921. évi XXXIII. törvénycikk 274-293. cikk. Elérhető: https://net.jogtar.hu/ezer-ev-torveny?docid=92100033.TV\&searchUrl=/ezer-ev-torvenyei\%3Fpagenum\%3D39 (2019. 02. 17.)

1923. évi XIV. törvénycikk a Dunára vonatkozó végleges szabályzat megállapítása tárgyában 1921. évi július hó 23-án Párisban kelt egyezmény becikkelyezéséről. Elérhető: https://net.jogtar. hu/ezer-ev-torveny?docid=92300014.TV\&searchUrl=/ezer-ev-torvenyei\%3Fpagenum\%3D39 (2019. 02. 17.)

1925. évi VII. törvény a Dunai Állandó Vízügyi Műszaki Bizottság hatáskörére és működésére vonatkozó szabályzat jóváhagyása tárgyában 1923. évi május hó 27-én Párisban kötött egyezmény becikkelyezéséről. Elérhető: https://net.jogtar.hu/jogszabaly?docid=92500007.TV\&celpa$\mathrm{ra}=139$ \&goto $=-1(2019.02 .17$. $)$ 